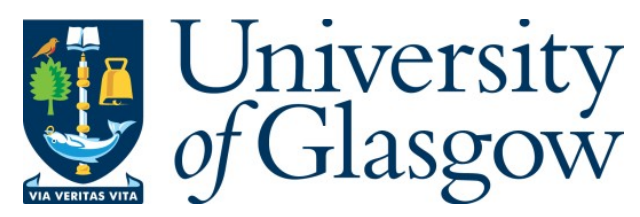

Pardos-Prado, S. (2020) Labour market dualism and immigration policy preferences. Journal of European Public Policy, 27(2), pp. 188-207.

(doi: $\underline{10.1080 / 13501763.2019 .1701536)}$

This is the Author Accepted Manuscript.

There may be differences between this version and the published version. You are advised to consult the publisher's version if you wish to cite from it.

$\underline{\text { https://eprints.gla.ac.uk/203042/ }}$

Deposited on: 19 November 2019

Enlighten - Research publications by members of the University of Glasgow http://eprints.gla.ac.uk 


\section{Title page}

Title: Labour market dualism and immigration policy preferences.

Author: $\quad$ Sergi Pardos-Prado

Title: $\quad$ Professor of Comparative Politics

Address: $\quad$ School of Social and Political Sciences

Adam Smith Building

University of Glasgow

G12 8RS

UK

Twitter:@@sergipardos

ORCID: $\quad$ 0000-0002-6944-326X

Email: $\quad$ sergi.pardos-prado@glasgow.ac.uk

Bio: $\quad$ Sergi Pardos-Prado is a full Professor of Comparative Politics at the University of Glasgow. Before this, he was an Associate Professor in Politics at Merton College, University of Oxford. His research lies at the intersection between political behaviour, European comparative politics, and comparative political economy. 


\title{
$\underline{\text { Labour market dualism and immigration policy preferences }}$
}

\begin{abstract}
What are the effects of labour market deregulation and increased immigration inflows on public attitudes towards immigration? Despite increased levels of dualism and free movement of labour in European countries over the last two decades, the effects of these policy developments are still unclear in the literature. This study argues that high concentrations of migrant workers in non-standard forms of employment decrease economic redistribution towards, and labour competition with, immigrants. Consequently, the politicisation of immigrant-native conflicts is paradoxically lower when immigration and labour market dualism cluster together at the occupational level. These claims are validated cross-nationally, and in a difference-in-differences setting analysing the impact of the 2005 German Immigration Act.
\end{abstract}

Keywords: attitudes towards immigration; immigration policy preferences; labour market; dualism; skill specificity; difference-in-differences.

Wordcount: 7,141

\section{Introduction}

The progressive deregulation of labour markets and the increasing mobility of foreign labour have been two defining features of European public policy over the last two decades (Häusermann and Schwander 2012; Kahanec and Zimmermann 2016) ${ }^{1}$. The specific impact of these processes on the politicisation of anti-immigrant and anti-globalisation attitudes, however, is unclear. On the basis of classical theories of labour market competition, decreased employment protection and increased foreign supply should theoretically increase anti-immigrant sentiment. Despite the enormous intuitive appeal of this theory, the existing scholarly evidence that supply-side shocks of immigrant competition are responsible for antiimmigrant backlash is dubious, at best (Hainmueller and Hiscox 2010; Malhotra et al. 2013; Dancygier and Donnelly 2013). Moreover, the few countries were the success of radical right

\footnotetext{
${ }^{1}$ The data that support the findings of this study are openly available at https://sergipardos.wixsite.com/sergipardos/publications.
} 
parties has been either prevented or most delayed (Ireland and Southern Europe being paradigmatic examples) are precisely those more hit by the Great Recession, dualism, and immigration inflows. In an era of unprecedented fragmentation of established European party systems, understanding the puzzling relationship between labour market policies, immigration inflows, and anti-immigrant sentiment seems more important than ever.

This paper argues that high concentrations of migrant workers in non-standard forms of employment (typical of de-regulated and dual labour markets) decrease immigrant-native competition and anti-immigrant sentiment. This means that the effects of country-level dualism and immigration will depend on the distribution of migrant workers in more or less precarious occupations. In a dual system, the labour market is sharply split between jobs with high levels of social and legal protection (i.e. insiders), and a significant share of unemployment or workers in temporary or non-standard forms of employment (i.e. outsiders) (Rueda 2005, 2006, 2007). In highly dual and deregulated systems, economic redistribution towards individuals in precarious occupations is very low (Fernández-Albertos and Manzano 2016). Therefore, when immigrants are highly clustered in non-protected occupations, the costs of redistribution towards immigrants are also very low, both for native insiders (who do not pay the bill for migrants) and outsiders (who get practically nothing in terms of social protection anyway). Apart from the lower costs of inter-ethnic redistribution, competition for jobs is also paradoxically low in systems where migrants are highly concentrated in unprotected occupations.

This paper makes two central contributions. First, it provides a novel occupational-based mechanism for the puzzling resilience to anti-immigrant politics by countries with high levels of immigration and precarious labour markets like Spain, Portugal, Ireland, and, to some 
extent, Greece. It also sheds light on the political consequences that certain combinations of labour market deregulation and immigration stocks can have. Inter-ethnic competition decreases in dual labour markets where immigrants disproportionally cluster in precarious forms of employment. This confirms the importance of occupational-level factors beyond canonical rich vs. poor divides measured at the individual or country levels. This also suggests that prospective economic risk (i.e. how much one can lose) is much more consequential than current economic conditions when understanding anti-immigrant backlash (Pardos-Prado and Xena 2019).

Secondly, this paper aims at a strong balance between external and internal validity by combining two empirical strategies. First, the theoretical expectations are validated using hierarchical linear models, the cumulative file of the European Social Survey (covering up to 28 countries over a decade), and OECD data. The results confirm that the presence of migrant workers in a given occupation is linked to anti-immigrant sentiment and restrictive immigration policy preferences only when levels of dualism are high.

The second empirical strategy deals with potential unobserved variable biases and the potential self-selection of specific types of migrants and natives into low-threat occupations. I use the German Socio-Economic Panel (1999-2014) and analyse longitudinally the effects of the German immigration law that took effect on the $1^{\text {st }}$ of January 2005 . After a progressive deregulation through the so-called Hartz reforms in the early 2000s, the German labour market became significantly more permissive only for highly qualified migrants in 2005 . In a difference-in-differences setting, I show that highly-skilled German workers (treated group) exposed to foreign competition showed more anti-immigrant backlash only when working in desirable occupations with a high proportion of insiders and levels of protection. 


\section{Migrant distribution and labour market characteristics}

The main expectation is that a high concentration of immigration in occupations with high levels of dualism should be associated with low levels of anti-immigrant sentiment in Europe. This particular distribution of immigration stocks across the occupational structure leads to: 1- low levels of inter-ethnic economic redistribution, and 2- low competition for jobs with migrants. The remainder of this section elaborates on the welfare redistribution and job competition aspects of the theory.

\section{Low inter-ethnic welfare redistribution}

A dual labour market is one with a sharp distinction between insiders and outsiders. Insiders are individuals working in occupations with high levels of legal and social protection. This means that insiders have permanent job contracts, and are costly to fire by employers. Outsiders, by contrast, work with temporary contracts and sometimes even without contract. Non-standard forms of employment are typically more precarious and less protected in terms of regulations and social compensation. In practice, a highly dual system has a large proportion of outsiders, and high levels of protection only for insiders (Rueda 2005; King and Rueda 2008). Labour market deregulations across Europe have increased differences between insiders and outsiders, lowered overall levels of employment protection, increased flexibility, and provided a greater range of non-standard contracts and forms of employment. 
The consequences of labour market dualism on individual social policy preferences and voting behaviour have been widely studied in the comparative political economy literature (Häusermann and Schwander 2012; Emmenger et al. 2012). Because of their different exposure to short and long-term risk, insiders tend to articulate different preferences over taxes and welfare than insiders. Among other things, dualism generates a sharp divide within working class constituencies traditionally voting for social-democratic parties (Rueda 2007). While most of the literature on social policy preferences has been very income-focused (Meltzer and Richard 1981; Alesina and Giuliano 2011), the study of dualism fits into a tradition of research more interested in risk and prospective economic shocks as determinants of preferences for economic redistribution and the welfare state (Iversen and Soskice 2001; Cusack et al. 2006; Rehm 2009; Alt and Iversen 2017).

As convincingly argued by Fernández-Albertos and Manzano (2016), dual labour markets are not particularly generous in terms of welfare redistribution, and strongly moderate preferences of outsiders. Even if low-income respondents are typically expected to be the primary beneficiaries of redistribution and to support generous welfare systems, this is significantly less so in highly dual systems. Assuming a contributory logic quite extended in European social security systems, welfare benefits tend to be a function of past contributions. In a highly dual system, workers contributing to and benefit from the system are mostly insiders. The consequence is that outsiders, with generally low levels of income and education, are paradoxically less interested in maintaining or expanding redistributive systems for which they are not eligible (Fernández-Albertos and Manzano 2016).

The expectation that average preferences for redistribution drop in segmented (or dual) markets is consistent with Alt and Iversen's (2017) work. When conceptualising the effects of 
dualism from a perspective of insurance against economic shocks, labour market segmentation generates a more uneven distribution of unemployment risk that lowers aggregate levels of redistribution preferences (Rehm 2009). What this logic does not necessarily contemplate, however, is that workers in precarious situations will not systematically prefer redistribution in highly dual systems either, and that the marginal welfare cost of immigration pressure can be negligible in those situations.

Immigration has also proved to be a strong determinant of redistribution preferences (Alesina and Glaeser 2004). More specifically, high levels of ethnic diversity in specific contexts have been shown to correlate with decreased provision of public goods and preferences for redistribution (Dahlberg et al. 2012). While the theoretical mechanisms behind this generalised finding are not always clear, the anti-solidarity effect of (perceptions of) immigration is widely documented (Facchini and Mayda 2009; Eger 2010; Finseraas 2012; Muñoz and Pardos-Prado 2019). Decreased levels of trust, competition for scarce material resources, and cultural distaste are some of the most likely mechanisms behind the antisolidarity effect of immigration.

When putting the consequences of dualism and immigration together, one would expect a stronger anti-immigrant and anti-solidarity effect in those contexts where immigrants benefit more from economic redistribution. Consequently, a high concentration of immigrants in highly dual occupations should reduce anti-immigrant backlash, since immigrants do not benefit from or are not even eligible to welfare benefits. This reduced ethnic penalty should affect preferences of both insiders and outsiders. On the one hand, native insiders do not expect to pay for inter-ethnic redistribution, given that benefits are based on labour market contributions, and that migrants are not clustered in occupations benefitting from welfare. On 
the other hand, native outsiders do not have reasons either to fear an ethnic penalty to welfare benefits. This is because they are not contributing much to the system due to their employment status (i.e. the cost does not increase), and do not compete for welfare resources that are not receiving anyway (i.e. the benefit does not decrease). This argument can be summarised in the following hypothesis:

- H1: a high concentration of immigrant workers in an occupational group is associated with lower (higher) anti-immigrant policy preferences when the levels of occupational dualism are high (low).

Low prospective job competition

Labour market features can also have consequences for the fear of losing one's job in a context with immigration, or for potential income losses when one can plausibly be substituted by a migrant. While individual and country-level analyses may be too coarse to grasp nuanced patterns of inter-ethnic competition, recent research has shown that zooming in on specific occupations and industries is a valuable strategy to unpack effects that could otherwise remain overlooked (Ortega and Polavieja 2012; Malhotra et al. 2013; Dancygier and Donnelly 2013; Pecoraro and Ruedin 2016; Polavieja 2016).

Influential research convincingly shows that inflows of migrants increasing the supply of labour have null effects on natives' attitudes towards immigration (Hainmueller and Hiscox 2010; Hainmueller and Hopkins 2014). This contradicts a long-standing intuition in the social sciences based on the factor-proportions model, expecting natives to dislike foreign workers with the same level of skill. 
Regardless of the level of immigration, however, new research shows that professions in low demand, with few exit options, and with low skill transferability are more sensitive to potential competition with migrants (Pardos-Prado and Xena 2019). This could seem paradoxical, since other dimensions of skill specificity (the opposite of skill transferability) also increase workers' feelings of insulation against migrant competition and substitutability (Ortega and Polavieja 2012; Polavieja 2016). However, prospective economic shocks in professions with low chances of relocation and requiring high investments in human capital are likely drivers of job market anxiety and anti-immigrant sentiment. The labour economics and political economy literatures have shown that high levels of skill specificity correlate indeed with higher income losses in case of unemployment or job mobility (Shaw 1987; Zengelidis 2008; Kambourov and Manovskii 2009), and with higher levels of support for social protection (Iversen and Soskice 2001).

Building upon the logic of prospective economic risk, workers have more to lose when facing competition in highly protected occupations. However, this risk should be conditional on how easy it is to find a similar level of protection and job status in case of need. When exposed to migrant competition, native workers should feel more threatened when they have more to lose: in contexts with high levels of protection (or low levels of dualism) and when their options to find a similar job or to transfer their skills in case of need are low. This leads to the second hypothesis:

- H2: a high concentration of immigrant workers in an occupational group is associated with anti-immigrant policy preferences when the levels of occupational dualism and skill transferability are low. 
The intuition behind $\mathrm{H} 2$ can be illustrated with examples. A machine operator in the chemical or automobile industries in Germany should feel higher levels of threat than a waiter working in restaurant services in Spain. From a classical labour market competition perspective, this wouldn't make any sense: a German machine operator has a vocational training degree, high levels of skill specificity, and relatively good levels of employment protection. However, when exposed to perceived sources of threat like immigrant competition, workers in German factories can fear higher marginal income losses and prospective shocks than in Spanish restaurants. Even if the level of precariousness of a Spanish waiter in a temporary and lowpayed contract is higher, the added economic cost of being exposed to immigration is low. Spanish restaurant services may have low levels of protection, but it is easier to transfer general skills to similar (unprotected) jobs in case of unemployment. 


\section{Cross-national analysis}

\section{Data and method}

The empirical analyses below rely on the cumulative file of the European Social Survey $(\mathrm{ESS})^{2}$, and include native-born individuals from up to 28 countries (when data for all countries are available) and six rounds (between 2002 and 2012). ESS data are ubiquitously used in comparative research on public opinion, and on attitudes towards immigration in particular. The high levels of validity, reliability, and comparability of survey items across countries and over time make the ESS an ideal dataset to use.

I use three items tapping into preferences for immigration policy, which is the main dependent variable. These questions ask whether the country of residence should admit immigrants 1) of the same race/ethnic group as the majority, 2) of different race/ethnic group from the majority, and 3) from poorer countries outside Europe. The four response categories have been recoded from positive to negative: 'allow many', 'allow some', 'allow a few', and 'allow none'. The three items have high inter-item reliability (Cronbach's alpha $=0.89)$ and have been added into a single scale measuring restrictive preferences for immigration policy. Table A1 in the Appendix replicate the main findings using attitudes towards immigration as the main dependent variable ${ }^{3}$.

As regards the independent variables, I strictly follow Fernández-Albertos and Manzano's way to operationalise labour market dualism (2016). First, I measure the share of outsiders

\footnotetext{
${ }^{2}$ https://www.europeansocialsurvey.org/ (01/10/18)

${ }^{3}$ Those items are 0-10 scales measuring attitudes on whether (1) immigration is bad or good for the country's economy, (2) the country's cultural life is undermined or enriched by immigrants, and (3) immigrants make the country a worse or better place to live. A Cronbach's alpha of 0.85 for the three items above indicates high reliability. These items are added up in an index ranging from 0 to 30, where higher values indicate antiimmigration attitudes.
} 
(i.e. unemployed or working without a permanent contract) per country. Second, I use the employment protection of labour index (EPL) compiled by the $\mathrm{OECD}^{4}$. More specifically, this index measures the strictness of employment protection concerning individual and collective dismissals (regular contracts). Third, I simply multiply the share of outsiders by the strictness of employment protection. In the analyses below, I compute this index per countryoccupation (on the basis of ISCO 4 digits international classification). Higher values in these indexes correspond to more dual labour markets, with a higher share of workers in nonstandard forms of employment and higher levels of employment protection ${ }^{5}$.

When averaging out all the ESS waves included here at the country level in Figure $1^{6}$, France stands out as the most dual system by far. Despite this extreme value, Greece, Portugal, Italy, and Ireland are significantly above average. Slovenia and the Netherlands are also slightly above average, but closer to the European mean. In sum, Figure 1 confirms the well-known and unusually high level of labour-market dualism in Southern European democracies. However, it is important to note that the index is operationalized at the occupational level in the statistical models below. The country-level aggregation is just an illustration that could be driven by a number of specific occupational groups.

\section{[FIGURE 1]}

The presence of immigrant workers is measured as the share of migrants (i.e. not being born in the country of residence) in each country-occupational group included in the analysis, on

\footnotetext{
${ }^{4}$ https://stats.oecd.org/ (02/10/2018)

${ }^{5}$ Given their skewed distribution, I use the natural logarithm of occupational dualism and occupational presence of immigrant workers in the statistical analyses below.

${ }^{6}$ The figures have been produced with the plottig package for Stata designed by Bischoff (2017).
} 
the basis of data available in the $\mathrm{ESS}^{7}$. All models also include a number of exogenous individual-level controls that have proved relevant in previous research on attitudes towards immigration: years of education, religiosity (measured on a 0-10 scale), age, and gender (where 1 is male, and 0 female). I also include some country-level controls imported from OECD databases, including the share of foreign-born population, GDP (in PPP), the unemployment rate, and the share of social expenditure over GDP.

My data structure is nested in a hierarchical way, whereby individuals (level 1) are nested in occupations (level 2), countries (level 3), and waves (level 4). Since we have variables measured at all levels of analysis, hierarchical linear models are a useful statistical technique to take into account the clustered structure of the data and avoid artificially deflated standard errors at higher levels of analysis (Hox 2010).

\section{Findings}

Table 1 presents a number of fully specified models predicting anti-immigration policy preferences. The first model shows the direct effect of occupational dualism and immigration. On average, high levels of dualism are significantly associated with anti-immigrant preferences, and occupational immigration levels have insignificant effects. The direct test of our first hypothesis of interest, however, relies on the interaction between the occupational presence of migrant workers and dualism shown in the second model. As expected by $\mathrm{H} 1$ above, the multiplicative term is negative and significant ( $99 \%$ level), indicating that the presence of immigrant co-workers is linked to lower anti-immigrant sentiment in occupations

\footnotetext{
${ }^{7}$ Measuring migrant shares from survey data is not perfect, as more settled migrants could be more likely to be included in national random probability samples. However, the bivariate correlation between migrant presence and dualism at the occupational level is -0.1 , suggesting that migrant workers are equally likely to be measured at all levels of occupational dualism, and that the results here are not biased in one obvious direction.
} 
with high levels of outsiders. Figure 2 depicts the marginal effect of immigrant presence across values of occupational dualism, and shows that the presence of immigrants becomes less threatening (i.e. its effect on anti-immigrant preferences decreases) as the proportion of outsiders in a given occupational group increases.

[TABLE 1]

[FIGURE 2 AND 3]

The third model in Table 1 tests $\mathrm{H} 2$ above. The expectation here is that a high concentration of immigrant workers is associated with stronger anti-immigrant sentiment when occupational dualism and skill transferability are low. In other words, immigrants are expected to be more threatening when working in more desirable and protected occupations with low job availability in case of need. This is tested with a 3-way interaction between occupational dualism, occupational immigration presence, and skill specificity. I measure skill specificity following the influential approach by Iversen and Soskice $(2001)^{8}$. Higher values in this measure mean higher levels of specificity, which correspond to major occupational groups with a higher level of task compartmentalisation and a relatively low share of the workforce able to perform those tasks. As shown in the triple multiplicative term of model 3 in Table 1, the interaction between dualism, immigration, and skill specificity is significant at the $95 \%$ level.

\footnotetext{
${ }^{8}$ This measure consists of the share of ISCO- 88 unit groups over the total number of unit groups in a major occupational cluster, divided by the share of workforce that the major group represents. This measure is then divided by the skill level of each large ISCO occupational group (Iversen and Soskice 2001).
} 
Figure 3 summarises the marginal effect of the share of migrants in a given ISCO occupational group on anti-immigrant attitudes ( $\mathrm{Y}$ axis) across values of occupational dualism ( $\mathrm{X}$ axis), for both the highest and the lowest level of skill transferability. Interestingly, the only significant effect on anti-immigrant sentiment is observed in jobs with low levels of dualism (left-hand side of the graph) and skill transferability. In other words, desirable jobs with high levels of protection that are more difficult to find are the ones more sensitive to immigrant competition. By contrast, low levels of dualism combined with high levels of skill transferability are insignificantly related to anti-immigrant preferences. Interestingly, immigrant competition has a completely flat slope when skill transferability is high. It is only when skill transferability is low that labour market competition and dualism can have significant effects. When there's not much availability of jobs at similar levels of skill, the interaction between dualism and immigration is particularly consequential: native workers react more negatively when competing with migrants for highly protected jobs.

The same models reported in Table 1 have been replicated with anti-immigrant attitudes (instead of immigration policy preferences) as the dependent variable in Table A1 in the Appendix, showing virtually identical results in terms of signs and significance of the key coefficients. Table A2 replicates the same models while controlling for the occupational average of migrant education and income, to deal with the possibility that migrant selection into different types of labour-market and welfare states are driving the results (Polavieja et al. 2018). Table A3 deals with the possibility of some structural breaks or time dependencies (especially after the 2008 financial crisis) driving the results with two alternative model specifications: including wave fixed-effects in a cross-classified specification, and controlling for a post-2008 dummy. Finally, Table A4 replicates Table 2 controlling for Gini scores of 
income inequality and the redistributive power of the welfare state (market Gini minus Gini after taxes and transfers).

\section{Difference in differences analysis}

\section{The 2005 German Migration Act}

The previous analyses confirm the intuition summarised in $\mathrm{H} 1$ : when migrants are highly clustered in precarious occupations not benefitting from welfare redistribution, levels of ethnic threat among native populations are low. The second hypothesis looked at immigrantnative conflicts from a labour market competition perspective. When levels of dualism and skill transferability are both low, competition with immigrants is more threatening. This means that migrants are perceived as more threatening when competing for scarce jobs with high and desirable levels of protection.

The analyses above are inevitably vulnerable to unobserved variables simultaneously shaping the distribution of migrants, the resulting level of job protection, and native attitudes in occupational groups. For instance, immigrants could self-select into less hostile workplaces and environments in the first place, which are subsequently deregulated by natives to avoid inter-ethnic transfers of different sorts. Similarly, native workers with high abilities could self-select into occupations with low ethnic-threat.

This section focuses on the causal impact of immigrant access to certain occupations with different levels of protection. More specifically, I look at the German Migration Act, which came to force on the $1^{\text {st }}$ of January 2015. This law was considered as a major overhaul of 
German migration policy, and the official recognition of Germany as an immigration country. The law was the result of a debate about the lack of skilled workers in the IT sector in the early 2000s. The Independent Commission Migration that resulted from that debate published a report in July 2001, confirming the need of highly qualified immigrants to offset labour market shortages ${ }^{9}$. The 2005 German Migration Act streamlined procedures in terms of residence requirements, and made citizenship accessible for the first time to children born in Germany to a foreign parent who had been legally residing for 8 years.

More importantly for labour market purposes, the law made a clear distinction between low and highly qualified migrants ${ }^{10}$. Migrants with low qualifications from non-EU countries were still denied access to simple jobs. Even job-seekers from Eastern European countries joining the EU in 2004 were not automatically granted access to the German labour market. By contrast, highly qualified migrants got a much better deal, regardless of where they came from. The new law allowed computer experts to stay indefinitely, foreign graduates in German universities to stay, and self-employed foreigners able to create jobs or make high economic investments to remain. The law also significantly streamlined bureaucratic procedures to obtain work and residence permits, but only for highly qualified migrants.

In all, the 2005 German Migration Act can be considered as an exogenous shock increasing migrant competition only for highly qualified German workers (treated group) and not for Germans below university qualifications (control group). If the theoretical expectations sketched out above are valid, the law should reduce anti-immigrant concern among the treated group, but only in those occupations with high levels of dualism. By contrast, allowing more foreign competition should increase anti-immigrant concern among those

\footnotetext{
${ }^{9}$ https://www.loc.gov/law/help/migration-citizenship/germany.php (17/02/2019)

${ }^{10} \mathrm{https}$ ://www.dw.com/en/first-german-immigration-law-takes-effect/a-1442681 (17/02/2019)
} 
affected by the law and working in more protected occupations ${ }^{11}$. I consider this a difficult case study, since highly educated individuals are particularly resilient to anti-immigrant attitudes.

The timing of dualism in the labour market is also randomised during the period analysed in this case study. The so-called Hartz reforms, officially called "Laws for Reform of the Job Market", were a major redefinition of the German labour market that was progressively unfolded in four big legal packages between December 2002 and January 2005 (Gaskarth 2014). It can thus be argued that there is also a legal intervention progressively increasing levels of dualism in some occupations, culminating in 2005, precisely at the same time when the Immigration Act comes to force. Previous research confirms that the Hartz reforms increased levels of dualism, shortened the typical duration of unemployment, reduced wages, and curtailed the generosity of benefits in some occupations (Eichhorts and Marx 2015; Bradley and Kügler 2019).

One could argue that native workers with transferable skills selected into occupations with higher levels of protection and less dualism in the first half of the 2000, before the immigration policy shock. However, for this to be a genuine source of concern for the difference in differences estimates on anti-immigrant concern below, one should expect this pattern of self-selection to be higher among highly educated individuals, and for these individuals to be able to anticipate the specific types of occupations affected by the 2005 immigration law. Even assuming such a tall order of strategic behaviour and policy

\footnotetext{
${ }^{11}$ The specific model specification reported in this section could be denoted as $Y_{i t}=a+b x_{i t}+\delta_{i}+w_{t}+\varepsilon_{i t}$, where $Y$ is the level of anti-immigrant concern of individual $i$ in year $t, b$ is the difference-in-difference estimate, and $x_{i t}$ is a dummy variable where 1 =individuals with a university degree in 2005 , and $0=$ everyone else. Note that, when modeling individual $\left(\delta_{i}\right)$ and survey-year $\left(w_{t}\right)$ fixed-effects, the difference-in-difference estimate captured by $b$ is mathematically equivalent to modeling the interaction between high levels of education and the year 2005.
} 
anticipation, one would expect the direction of the bias to be the opposite as the one expected here. The theory expects highly educated individuals moving into highly protected occupations (i.e. with lower dualism) to be less happy about immigration. It is thus unclear why they would rationally self-select into occupations with more inter-ethnic competition. In any case, the empirical analyses below will assess the plausibility of the assumption of parallel trends between treated and control groups before the policy intervention, which is indeed key for the validity of this methodological strategy.

\section{Findings}

The study of the 2005 German Immigration Act allows for a difference-in-differences set up, where one would expect levels of anti-immigrant concern to vary after the policy shock in the treated group but not in the control group. More specifically, I use the core module of the German Socio-Economic Panel (GSOEP), consisting of 16 waves (from 1999 to 2014). The dependent variable is based on the question, "How concerned are you about Immigration to Germany?" with three categories: Very concerned, Somewhat concerned, Not concerned at all. Responses have been recoded to range from not concerned at all to very concerned. The treatment is a dummy variable where respondents with university education in 2005 get the value 1 , and everyone else gets the value 0 (i.e. respondents with qualifications below university degree, and individuals with a university degree in any other year).

Table 2 reports a number of longitudinal difference-in-differences models with individual fixed-effects, survey-year fixed effects, and clustered standard errors at the level of the individual $^{12}$. The first column includes the whole of the German labour market, and shows an

\footnotetext{
${ }^{12}$ Table A5 in the Appendix replicates the results shown in Table 2 with bootstrapped standard errors.
} 
insignificant effect of the treatment variable. The second column replicates the same analysis only including occupations above average levels of dualism (0.14). Consistently with our theory, the coefficient of the treatment variable is negative and significant $(b=-0.08$; $s e=$ 0.03; $\mathrm{p}=0.02$ ). This indicates that, when exposed to potentially higher levels of foreign competition, highly skilled individuals working in dual occupations with little aggregate protection became less concerned with immigration. The third model in Table 2 replicates the same analysis only including occupations below average levels of dualism. In this case, the sign of the treatment coefficient flips and becomes positive, even if statistically insignificant.

\section{[TABLE 2]}

Even if dualism levels are not randomised as such, the last model in Table 2 models the interaction between the treatment variable and occupational dualism. Consistently with my expectations, the multiplicative term is negative and highly significant. Figure 4 depicts the marginal effect of our treatment variable increasing anti-immigrant concern (high values on the $\mathrm{Y}$ axis) across levels of occupational dualism ( $\mathrm{X}$ axis). In striking consistency with the cross-national analyses shown above, exposure to increased migrant competition (proxied by the liberalisation of immigration law in 2005 affecting only highly skilled Germans) increased anti-immigrant concern only at very low levels of dualism, in occupations where almost everyone enjoys permanent contracts and high levels of protection. However, even keeping high levels of education constant, anti-immigrant concern decreases in occupations where migrants would mostly access non-standard and less desirable jobs.

[FIGURE 4] 
The validity of the estimates shown in Table 2 naturally depends on the assumption of parallel trends across treated and control groups before the treatment. Table A6 in the Appendix replicates the second model in Table 2 (the one validating our main expectation) by interacting the treated group (highly skilled workers) with each pre-treatment period since 1999. The results show insignificant differences in anti-immigrant concern between treated and control groups up to 2005, and in the first post-treatment period in 2006. This robustness check gives some plausibility to the parallel trends assumption, and gives credence to the expectation that it was implausible for treated individuals to anticipate the combined effects of dualism and immigrant exposure that came about in 2005.

Still in terms of parallel trends, it could be argued that, despite the policy shock showing significant results, individuals with higher and non-higher educational levels still managed to self-select into different occupational profiles with different levels of economic protection and ethnic threat. Table A7 in the Appendix shows the same substantive results as Table 2 while controlling for unit-specific trends (interacting the group of highly educated individuals with a time trend). Those trends come out as insignificant, and the sign and significance of the treatment variables remain unchanged.

I also replicate our results using Abadie's (2005) semiparametric difference-in-differences estimator. This technique consists of weighting the trend for the untreated respondents based on their propensity to select into the treatment, in order to give more weight to untreated respondents who were highly likely to get treated. The weights are calculated on the basis of income, social class (Erikson et al 1979), gender, age, having a temporary contract, years of education, skill specificity (Iversen and Soskice 2001), and occupational unemployment (Rehm 2009). When replicating the second model in Table 2, Abadie's method confirms the 
expected negative and highly significant effect of our treatment variable on anti-immigrant concern $(b=-0.34 ; s e=0.03 ; p=0.000)$, and gives further reassurance that the assumption of parallel trends is not violated in any obvious way.

Finally, Table A8 in the Appendix performs a robustness check with an even higher level of homogeneity between treated and control groups. This analysis only includes individuals with a university degree throughout the whole time span. In this case, the treated (control) group corresponds to highly educated individuals in occupations with above (below) average levels of dualism. As expected, the coefficient of the treatment variable is negative and significant $(b=-0.07 ; \mathrm{se}=0.03 ; \mathrm{p}=0.01)$.

\section{Conclusions}

What are the effects of labour market deregulation and increased immigration inflows on immigration attitudes and policy preferences? Despite the prominence of increased labour market dualism and free movement of labour in European countries over the last two decades, their independent or joint effect on the politicisation of immigration sentiment is unclear. In fact, labour market policies and economic threat paradigms have been ubiquitously questioned in recent and influential scholarship.

The main argument presented here is that exposure to immigrant competition hardly ever increases anti-immigrant sentiment in contexts of deregulation. When zooming into occupational levels of analysis within countries, it is possible to observe low levels of nativeimmigrant conflict when migrants are clustered in unregulated occupations with high levels of dualism. If anything, anti-immigrant sentiment increases in occupational groups with a 
large proportion of insiders and high average levels of job protection. In that case, levels of inter-ethnic redistribution and competition for desirable jobs increases. The interaction between immigration and labour market dualism at the occupational level is strong, negative and significant when predicting anti-immigrant sentiment and policy preferences using ESS and OECD data including close to 30 countries during more than a decade.

The main mechanism suggested to make sense of the findings is the low level of economic redistribution towards highly dual occupations, which typically involve low employment protection and social benefits (Fernandez-Albertos and Manzano 2016). The interaction between immigrant presence and labour market dualism is significant when predicting antiimmigrant attitudes. The second mechanism involves the joint effect of labour market dualism and skill specificity (Pardos-Prado and Xena 2019). Higher levels of economic threat are found in jobs relying on a large proportion of secure contracts with low skill transferability and demand. This means that native workers react more negatively to migrant competition in occupational groups where finding similarly desirable jobs in case of need is very difficult.

The causal effect of immigrant exposure becomes particularly plausible when analysing the effect of the 2005 German Immigration Act, which came to force precisely after a progressive deregulation of the labour market via the Hartz reforms. The 2005 Immigration Act reduced labour market and residence barriers to highly skilled migrants. When assessing the policy shock in a difference-in-differences setting, highly educated Germans became less concerned with immigration in occupations with high levels of dualism, but more concerned with immigration in jobs with more insiders and encompassing levels of protection. This 
finding is replicated through a myriad of robustness checks and ways to operationalise the control group. 


\section{References}

Abadie, A. (2005). "Semiparametric Difference-in-Differences Estimators.” Review of Economic Studies 72(1): 1-19.

Alesina, A. and Glaeser, E. (2004) Fighting Poverty in the U.S. and in Europe:

A World of Difference. New York: Oxford University Press.

Alesina, A. and Giuliano, P. (2011) "Preferences for Redistribution ", in Handbook of Social Economics. North Holland, pp. 93:132.

Alt, J. and Iversen, T. (2017) “Inequality, Labor Market Segmentation, and Preferences for Redistribution”, American Journal of Political Science, 61(1): 21-36.

Bischof, D. (2017) "New Graphic Schemes for Stata: plotplain and plottig." The Stata Journal 17(3):748-759.

Bradley, J. and Kügler, A. (2019) "Labor market reforms: An evaluation of the Hartz policies in Germany", European Economic Review, 113: 108-135.

Cusack, T., Iversen, T. and Rehm, P. (2006) "Risks at work: the demand and supply sides of government redistribution." Oxford Review of Economic Policy 22(3).

Dahlberg, M., Edmark, K. and Lundqvist, H. (2012) "Ethnic diversity and preferences for redistribution." Journal of Political Economy 120(1):41-76. 
Dancygier, R. and Donnelly, M. J. (2013) “Sectoral Economies, Economic Contexts, and Attitudes toward Immigration." The Journal of Politics 75(1): 17-35.

Eger, M.A. (2010) "Even in Sweden: the effect of immigration on support for welfare state spending." European Sociological Review 26(2): 203-217.

Eichhorts, W., and Marx, P. (2015) Non-Standard Employment in Post-Industrial Labour Markets. Edward Elgar. https://www.e-elgar.com/shop/non-standard-employmentin-postindustrial-labour-markets.

Emmenegger, P., Häusermann, S., Palier, B., and Seelib-Kaiser, M. (eds.) (2012) The Age of Dualization. The Changing Face of Inequality in Deindustrializing Societies. Oxford: Oxford University Press.

Erikson, R., Goldthorpe, J. H. and Portocarero, L. (1979) “Intergenerational Class Mobility in Three Western European Societies: England, France and Sweden.” British Journal of Sociology 30(4): 415-41.

Facchini, G. and Mayda A. N. (2009) "Does the welfare state affect individual attitudes toward immigrants? Evidence across countries." The Review of Economics and Statistics 91(2):295-314.

Fernandez-Albertos, J. and Manzano, D. (2016) "Dualism and support for the welfare state." Comparative European Politics 14:349-375. 
Finseraas, H. (2012) "Poverty, Ethnic Minorities among the Poor, and Preferences for Redistribution in European Regions.” Journal of European Social Policy 22(2): 164-80.

Gaskarth, G. 2014. “The Hartz Reforms.” Technical report, Centre for Policy Studies. https://www.cps.org.uk/_les/reports/original/141024133732-TheHartzReforms.pdf.

Hainmueller, J. and Hiscox, M. J. (2010) “Attitudes toward Highly Skilled and Low-skilled Immigration: Evidence from a Survey Experiment." American Political Science Review, 104:61-84

Hainmueller, J. and Hopkins, D.J. (2014) "Public Attitudes Toward Immigration", Annual Review of Political Science 17:225-49.

Häusermann, S. and Schwander, H. (2012) "Varieties of dualization? Labor market segmentation and insider-outsider divides across regimes”. In: P. Emmenegger, S. et al. (eds.) The Age of Dualization. The Changing Face of Inequality in Deindustrializing Societies. Oxford: Oxford University Press.

Hox, Joop (2010) Multilevel Analysis: Techniques and Applications. London: Routledge.

Iversen, T. and Soskice, D. (2001) "An asset theory of social policy preferences." American Political Science Review 95(4):875-894.

Kahanec, M. and Zimmermann, K.F. (2016) Labor Migration, EU Enlargement, and the Great Recession. Berlin: Springer. 
Kambourov, G. and Manovskii, I. (2009) “Occupational Mobility and Wage Inequality." Review of Economic Studies 76:731-759.

King, D. and Rueda, D. (2008) "Cheap labor: The new politics of 'bread and roses' in industrial democracies", Perspectives on Politics 6(2): 279-297.

Malhotra, N., Margalit, Y. and Hyunjung Mo, C. (2013) "Economic Explanations for Opposition to Immigration: Distinguishing between Prevalence and Conditional Impact." American Journal of Political Science 57(2):391-410.

Meltzer, A.H. and Richard, S.F. (1981) “A Rational Theory of the Size of Government." Journal of Political Economy 89:914-27.

Muñoz, J. and Pardos-Prado, S. (2019) "Immigration and Support for Social Policy. An Experimental Comparison of Universal and Means-Tested Programs." Political Science Research and Methods, 7(4):717-735.

Ortega, F. and Polavieja, J.G. (2012) "Labor-market exposure as a determinant of attitudes toward immigration." Labour Economics 19:298-311.

Pardos-Prado, S. and Xena, C. (2019) “Skill Specificity and Attitudes towards Immigration”, American Journal of Political Science, 63(2):286-304 
Pecoraro, M., and Ruedin, D. (2016). “A Foreigner Who Does Not Steal My Job: The Role of Unemployment Risk and Values in Attitudes toward Equal Opportunities.” International Migration Review 50(3): 628-66.

Polavieja, J.G. (2016). "Labour-market competition, recession and anti-immigrant sentiments in Europe: occupational and environmental drivers of competitive threat." Socio-Economic Review 14(3): 395-417.

Polavieja, J.G., Fernández-Reino, M. and Ramos, M. (2018) “Are Migrants Selected on Motivational Orientations? Selectivity Patterns amongst International Migrants in Europe”, European Sociological Review, 34(5): 570-588.

Rehm, P. (2009) "Risks and Redistribution. An Individual-Level Analysis." Comparative Political Studies 42(7):855-881.

Rueda, D. (2005) "Insider-outsider politics in industrialized democracies: The challenge to social democratic parties”. American Political Science Review 99(1): 61-74.

Rueda, D. (2006) "Social democracy and active labour market policies: Insiders, outsiders, and the politics of employment promotion". British Journal of Political Science 36(3): 385406.

Rueda, D. (2007) Social Democracy Inside Out: Partisanship and Labor Market Policy in Industrialized Democracies. Oxford: Oxford University Press. 
Shaw, K.L. (1987) "Occupational Change, Employer Change, and the Transferability of Skills." Southern Economic Journal 53(3):702-719.

Zangelidis, A. (2008) "Occupational and Industry Specificity of Human Capital in the British Labour Market." Scottish Journal of Political Economy 55(4):420-443. 
TABLES

Table 1- Hierarchical Linear Models predicting anti-immigrant attitudes

\begin{tabular}{|c|c|c|c|}
\hline & Model 1 & Model 2 & Model 3 \\
\hline \multirow[t]{2}{*}{ Occupational migrant share } & -0.072 & -0.03 & -0.057 \\
\hline & $(0.15)$ & $(0.02)$ & $(0.04)$ \\
\hline \multirow[t]{2}{*}{ Occupational dualism } & $0.180 * * *$ & -0.049 & $-0.316^{* *}$ \\
\hline & $(0.03)$ & $(0.07)$ & $(0.13)$ \\
\hline \multirow[t]{2}{*}{ Years of education } & $-0.116^{* * *}$ & $-0.115^{* * *}$ & $-0.110 * * *$ \\
\hline & $(0.00)$ & $(0.00)$ & $(0.00)$ \\
\hline \multirow[t]{2}{*}{ Religiosity } & $-0.028 * * *$ & $-0.028 * * *$ & $-0.027 * * *$ \\
\hline & $(0.00)$ & $(0.00)$ & $(0.00)$ \\
\hline \multirow[t]{2}{*}{ Age } & $0.013 * * *$ & $0.013^{* * *}$ & $0.013^{* * *}$ \\
\hline & $(0.00)$ & $(0.00)$ & $(0.00)$ \\
\hline \multirow[t]{2}{*}{ Gender } & $0.100^{* * *}$ & $0.101 * * *$ & $0.156 * * *$ \\
\hline & $(0.02)$ & $(0.02)$ & $(0.02)$ \\
\hline \multirow[t]{2}{*}{ Country $\%$ foreign born } & 0.004 & 0.003 & 0.005 \\
\hline & $(0.02)$ & $(0.02)$ & $(0.02)$ \\
\hline \multirow[t]{2}{*}{ Country GDP } & $-0.000 * * *$ & $-0.000 * * *$ & $-0.000 * * *$ \\
\hline & $(0.00)$ & $(0.00)$ & $(0.00)$ \\
\hline \multirow[t]{2}{*}{ Country unemployment } & 0.017 & 0.014 & 0.014 \\
\hline & $(0.02)$ & $(0.02)$ & $(0.02)$ \\
\hline \multirow[t]{2}{*}{ Country social expenditure } & 0.016 & 0.018 & 0.018 \\
\hline & $(0.02)$ & $(0.02)$ & $(0.02)$ \\
\hline \multirow[t]{2}{*}{ Migrant share $\mathrm{x}$ dualism } & & $-0.089 * * *$ & $-0.173 * * *$ \\
\hline & & $(0.03)$ & $(0.06)$ \\
\hline \multirow[t]{2}{*}{ Skill specificity } & & & $0.242 * * *$ \\
\hline & & & $(0.08)$ \\
\hline Migrant share $\mathrm{x}$ skill specificity & & & 0.008 \\
\hline
\end{tabular}




\begin{tabular}{|l|c|c|c|}
\hline & & & $(0.04)$ \\
\hline Dualism x skill specificity & & & $-0.266^{* *}$ \\
\hline & & & $(0.10)$ \\
\hline Migrant share x dualism x skill specificity & & & $-0.088^{* *}$ \\
\hline & & & $(0.04)$ \\
\hline Intercept & $6.201^{* * *}$ & $6.319 * * *$ & $6.347^{* * *}$ \\
\hline & $(0.52)$ & $(0.52)$ & $(0.53)$ \\
\hline Wave intercept variance & 0 & 0 & 0 \\
\hline & $(0)$ & $(0)$ & $(0)$ \\
\hline Country intercept variance & 0.362 & 0.362 & 0.364 \\
\hline & $(0.07)$ & $(0.07)$ & $(0.07)$ \\
\hline Occupational intercept variance & 0.117 & 0.113 & 0.103 \\
\hline Log Likelihood & $(0.01)$ & $(0.01)$ & $(0.01)$ \\
\hline BIC & 4.62 & 4.62 & 4.61 \\
\hline & 53177 & 53177 & 53177.000 \\
\hline & -116746 & -116729 & -116652 \\
\hline & 233654.5 & 233631.7 & 233521.3 \\
\hline & & & $(0.03)$ \\
\hline
\end{tabular}

Standard errors between brackets

$* 0.1 * 0.05 * * * 0.01$

Source: ESS cumulative file and OECD 
Table 2- Difference-in-differences models predicting anti-immigrant concern

\begin{tabular}{|l|c|c|c|c|}
\hline & $\begin{array}{c}\text { Model 1 } \\
\text { (whole } \\
\text { sample) }\end{array}$ & $\begin{array}{c}\text { Model 2 } \\
\text { duagh } \\
\text { dualism) }\end{array}$ & $\begin{array}{c}\text { Model 3 } \\
\text { (low } \\
\text { dualism) }\end{array}$ & $\begin{array}{c}\text { Model 4 } \\
\text { (whole } \\
\text { sample) }\end{array}$ \\
\hline Treated & -0.004 & $-0.08^{* *}$ & 0.01 & $0.03 * *$ \\
\hline & $(0.01)$ & $(0.03)$ & $(0.01)$ & $(0.01)$ \\
\hline Occupational dualism & & & & 0.001 \\
\hline Treated x Occupational Dualism & & & & $(0.01)$ \\
\hline & & & & $-0.25 * *$ \\
\hline Survey-year fixed effects & YES & YES & YES & YES \\
\hline Individual fixed-effects & YES & YES & YES & YES \\
\hline N observations & 346,674 & 76,678 & 269,996 & 346,674 \\
\hline N individuals & 61,778 & 38,189 & 55,946 & 61,778 \\
\hline
\end{tabular}

Standard errors between brackets

$* 0.1 * * 0.05 * * * 0.01$

Source: German Socio-Economic Panel (1999-2014) 


\section{FIGURES}

Figure 1- Labour market dualism across countries (average values)

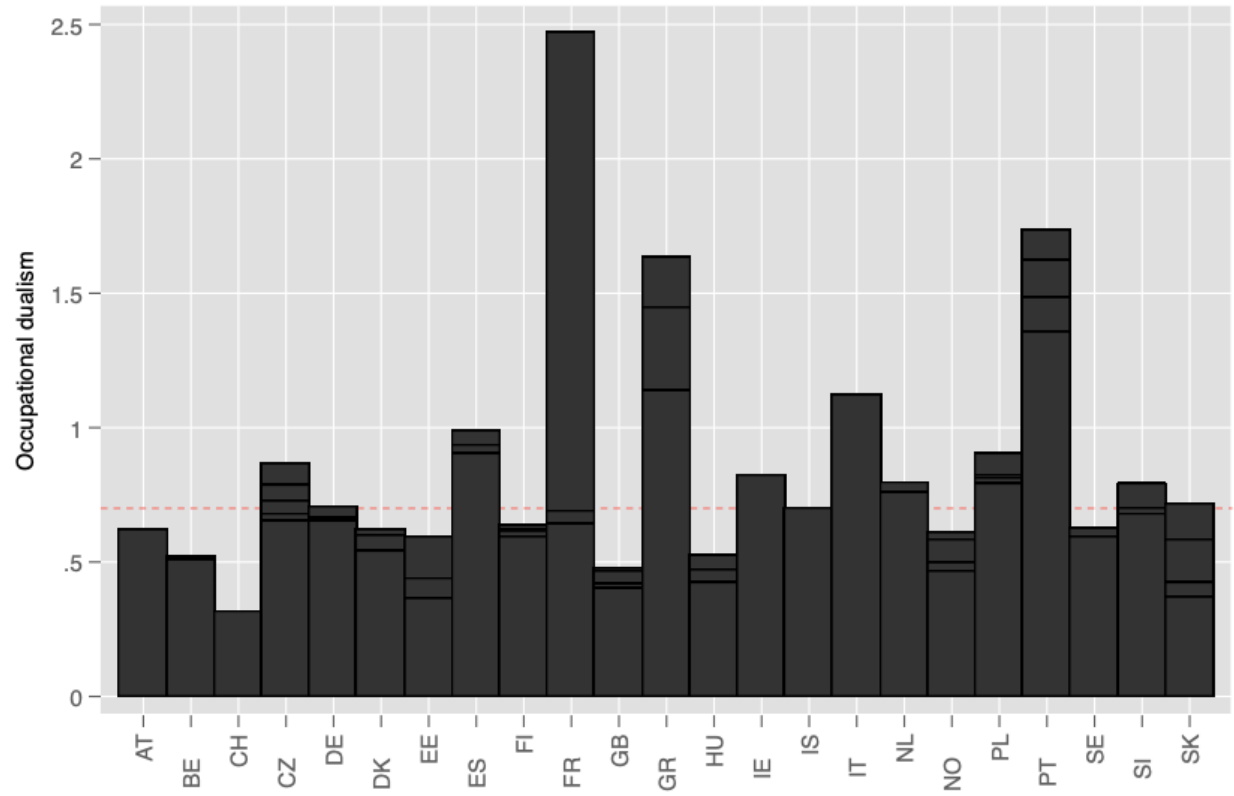

Figure 2- Marginal effect of \% occupational migration on anti-immigrant policy preferences across values of occupational dualism

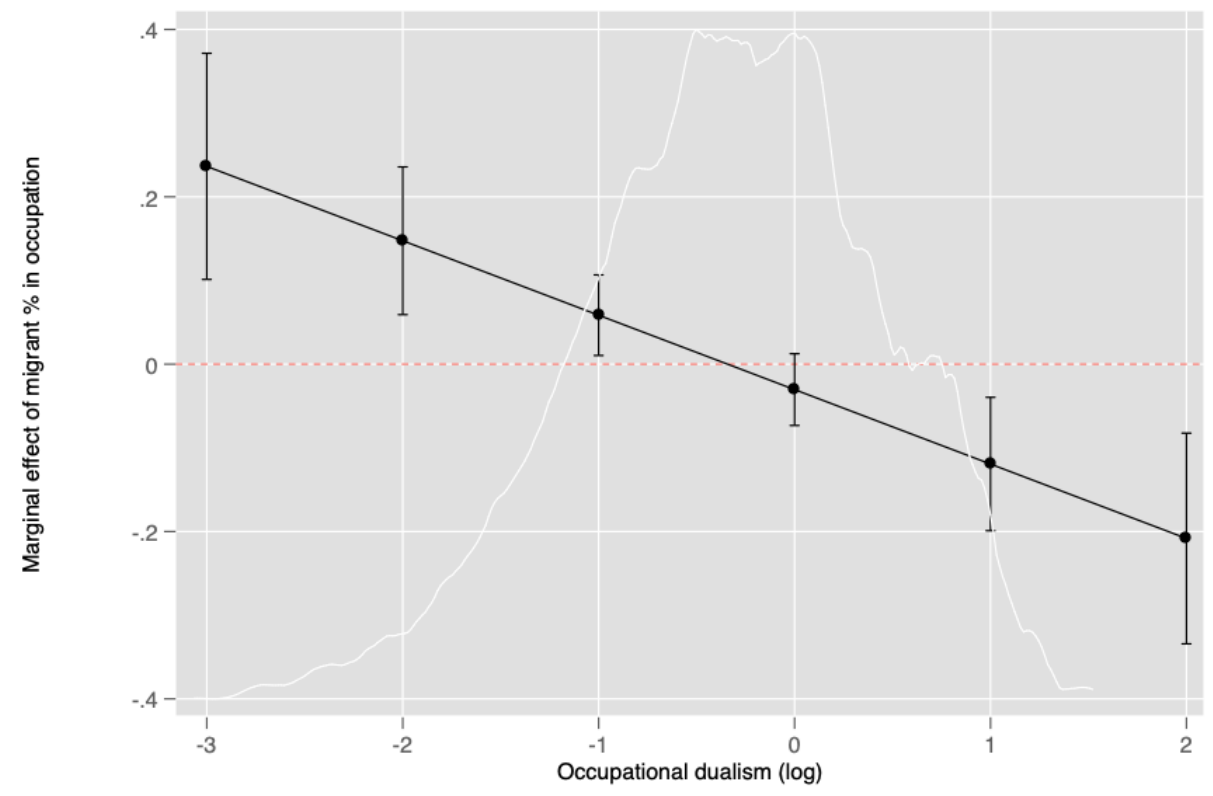


Figure 3- Marginal effect of \% occupational migration on anti-immigrant policy preferences across values of occupational dualism and skill transferability

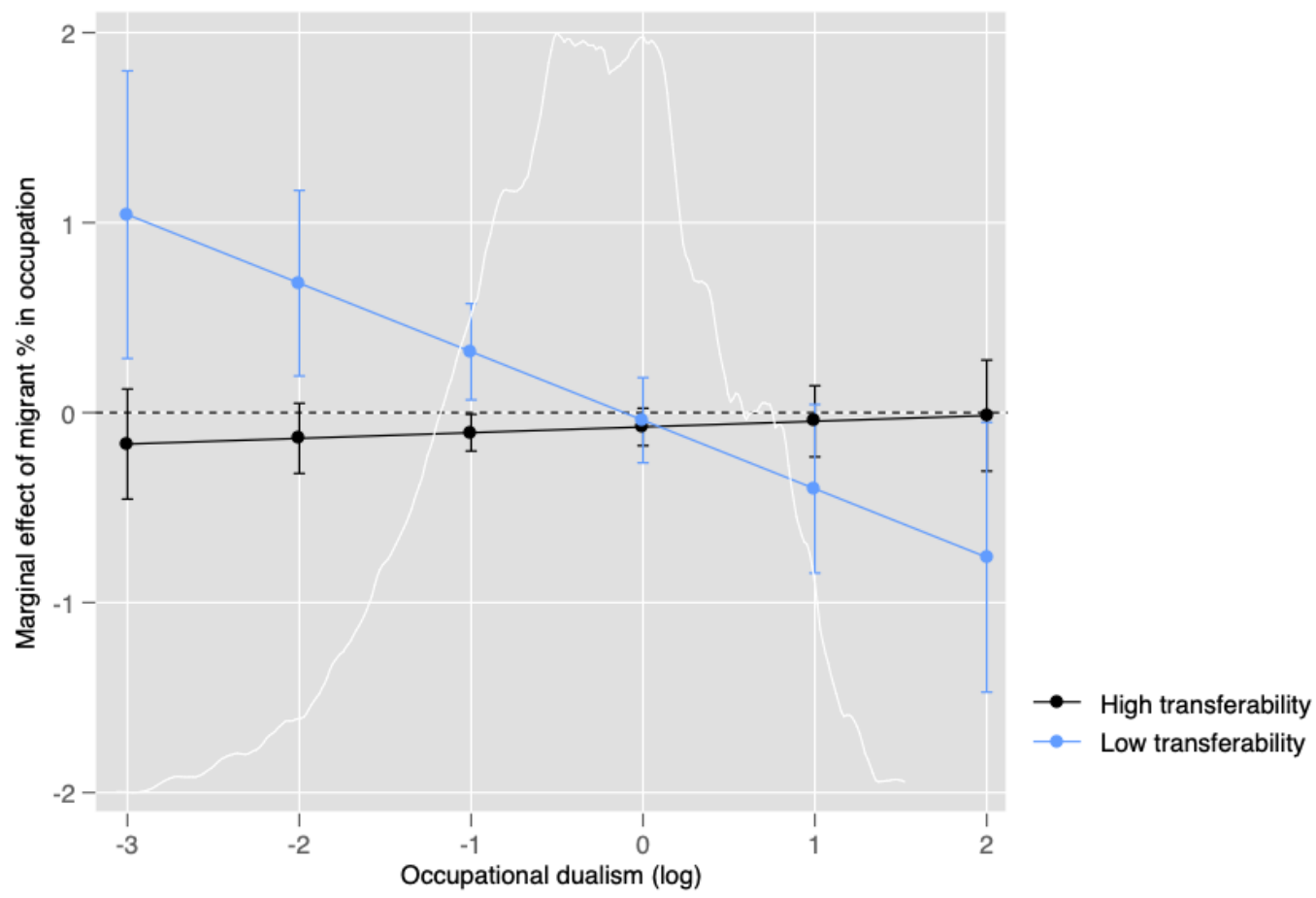

Figure 4- Marginal effect of treated group (i.e. highly skilled individuals exposed to the 2005 German Immigration Act) across values of occupational dualism

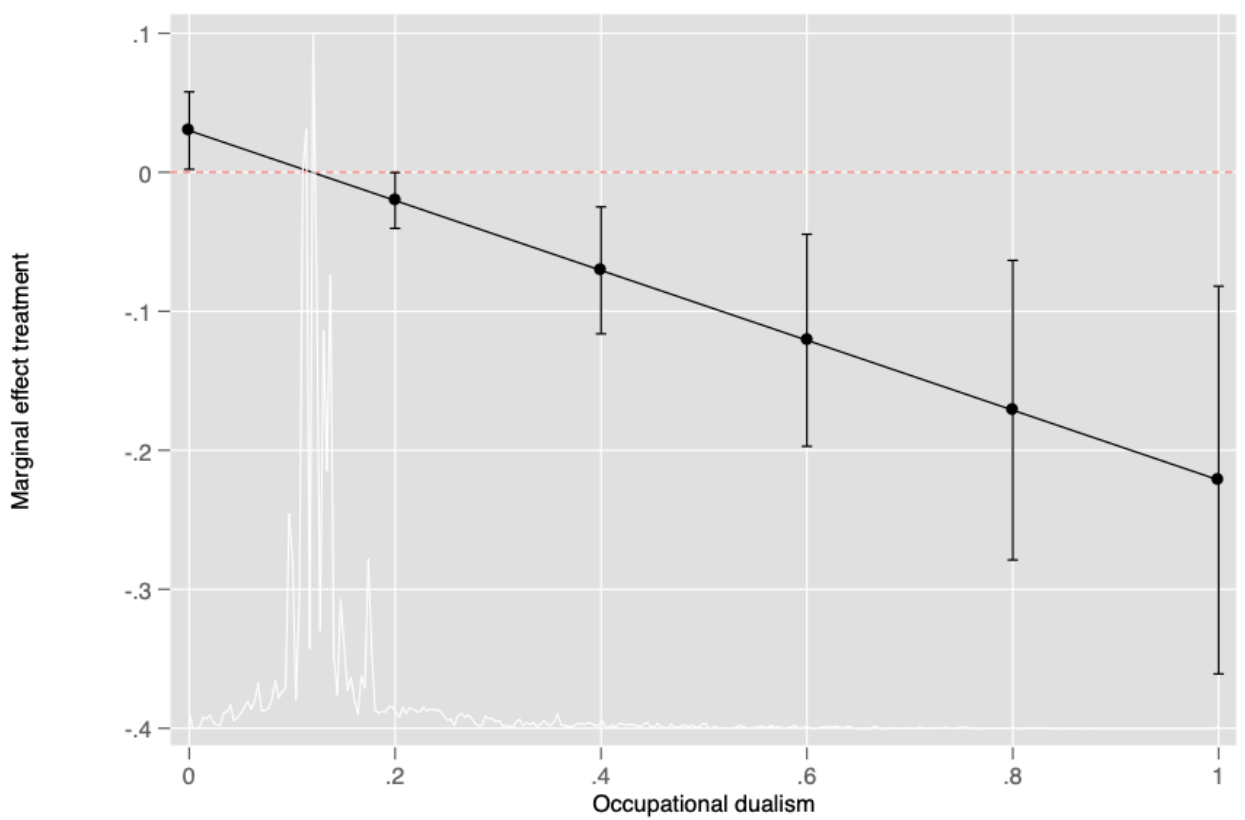

